\title{
Типоморфические и типохимические особенности апатита из гранитов Бадьяюского массива (Приполярный Урал)
}

Денисова Ю.В.

Институт геологии Коми НЦ УрО РАН, Сыктывкар, yulden777@yandex.ru

Аннотация. В работе представлены результаты изучения типоморфических и типохимических особенностей апатита Бадьяюского гранитного массива. В исследованных гранитах выявлены фторапатиты гексагонального призматического габитуса (І тип) и гексагонального дипирамидально- призматического габитуса (II тип). На основе различных морфологических особенносей выявлено, что апатит I типа является поздней и более низкотемпературной генерацией минерала, чем апатит II типа. Применение термометрии насыщения Е. Ватсона, Т. Харрисона и Ф. Беа позволило установить, что апатит и апатитсодержащая порода (гранит) образовались при температурах от $634^{\circ} \mathrm{C}$ до $863^{\circ} \mathrm{C}$.

Ключевые слова: апатит, гранит, Бадьяюский массив, Приполярный Урал.

\section{Typomorphic and typochemical features of apatite from the Badyayu massif granites (Subpolar Urals)}

\section{Denisova Yu.V.}

Institute of geology of Komi SC UB RAS, Syktyvkar, yulden777@yandex.ru

\begin{abstract}
The paper presents the results of studying the typomorphic and typochemical features of apatite in the Badyayu granite massif. Fluorapatites of hexagonal prismatic habitus (type I) and hexagonal dipyramidal - prismatic habitus (type II) were found in the studied granites. Based on various morphological features, it was revealed that type apatite I is a later and lower-temperature generation of the mineral than apatite II. Application of saturation thermometry by E. Watson, T. Harrison, and F. Bea allowed us to establish that apatite and apatite-containing rock (granite) were formed at temperatures from $634^{\circ} \mathrm{C}$ to $863^{\circ} \mathrm{C}$.
\end{abstract}

Key words: apatite, granite, the Badyayu massif, Subpolar Urals.

\section{Введение}

Гранитоиды сальнерско- маньхамбовского интрузивного комплекса Приполярного Урала, и в частности Бадьюяский гранитный массив (в среднем 650 г/т), характеризуется повышенным содержанием одного из наиболее распространенных акцессорных минералов магматических пород, которым является апатит. Тем не менее, последние изучения бадьяюских апатитов датируется 1968 годом (Фишман и др., 1968). Целью представленной работы является изучение типоморфологических и типохимических особенностей апатита Бадьяюского гранитного массива. Кроме того, минерал будет рассмотрен в качестве индикатора термических условий гранитогенеза.

\section{объект исследования}

В северо- восточной части Приполярного Урала в пределах Народо- Итьинского хребта расположено несколько гранитных массивов, одним из которых является Бадьяюский массив. По предположению Л.В. Махлаева и В.И. Мизина (Махлаев, 1996) рассматриваемый массив наряду с рядом лежащим Яротским гранитным массивом является продолжением расположенного северней Лемвинского гранитного массива, а именно частью единого трещинного плутона, приуроченного к субмедиальному взбросу. Массив, представляющий собой пластообразное гранитное тело длиной около 10 км и шириной до 1 км, пересекает долины рек Малая и Большая Бадьяю в их верховьях и далее прослеживается на юг до р. Селемью (рис. 1). Породами этого массива являются массивные лейкократовые (аляскитовые) граниты, для которых характерно повсеместное проявление катаклаза. По классификации Б. Чаппела Бадьяюский гранитный массив относится к А - типу. 


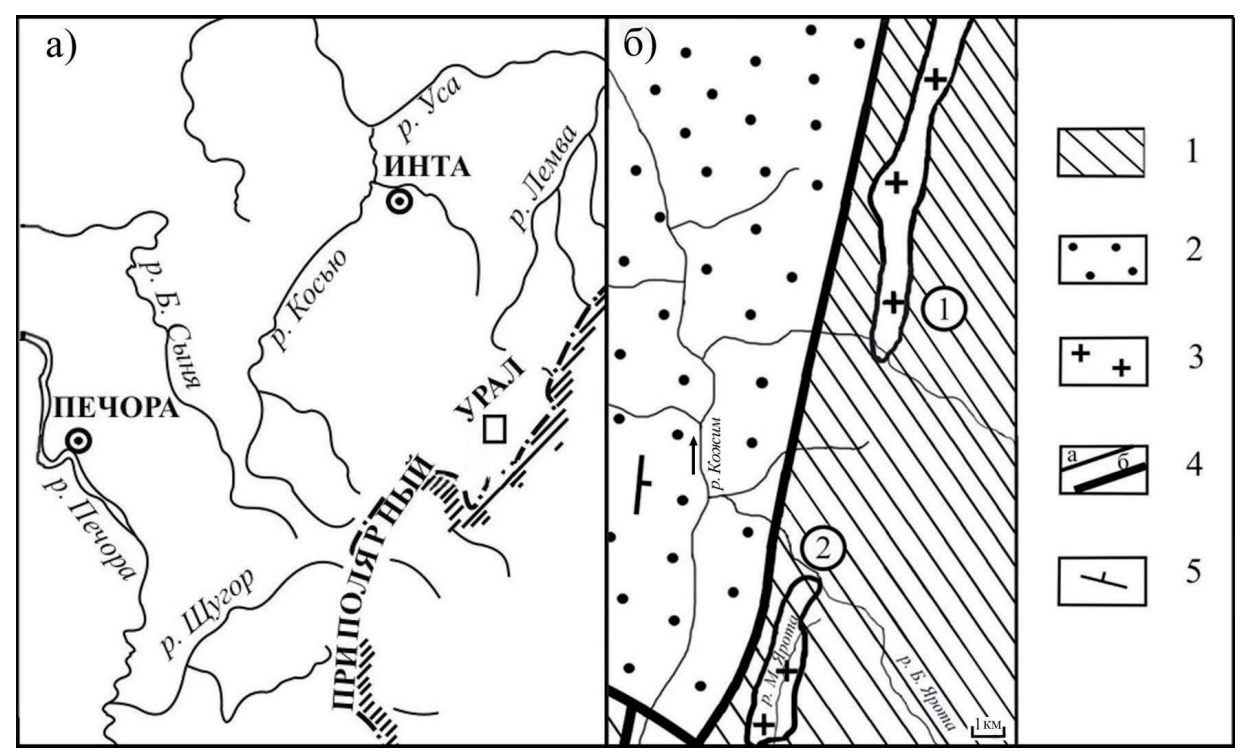

Рис. 1. а) Обзорная карта района. б) Бадьяюский гранитный массив (по Л.В. Махлаеву).

1 - слюдяно-кварцевые сланцы, порфиры, порфириты, прослои мраморов и кварцитов; 2 - терригенно- карбонатные отложения; 3 - граниты; 4 - геологические границы: а - стратиграфические и магматические, б - тектонические; 5 - элементы залегания плоскостных структур. Массивы (цифры в кружочках): 1 - Бадьяюский; 2 - Яротский.

Fig. 1. a) Overview map of the area. b) The Badyayu granite massif (after L.V. Makhlaev).

1 - mica-quartz shales, porphyry, porphyrite, interlayers of marbles and quartzites; 2 - terrigenous-carbonate deposits; 3 - granites; 4 - geological borders: a - stratigraphic and igneous, b - tectonic; 5 - elements of the occurrence of planar structures. Massifs (numerals in circles): 1 - the Badyayu massif; 2 - the Yarot massif.

\section{Типоморфические и типохимические особенности апатита Бадъяюского массива}

При изучении морфологических особенностей акцессорного апатита Бадьяюского массива выявлено два морфотипа минерала. К I типу отнесены светло-желтые полупрозрачные удлиненные кристаллы гексагонального призматического габитуса. Размер таких кристаллов 0.30-0.60 мм, коэффициент удлинения 2-4. Облик минерала представлен комбинацией призмы (1010) и пинакоида (0001). Поверхность граней часто трещиноватая со следами естественного травления. Характерными включениями этого типа являются слюды (биотит, мусковит), кварц, циркон, пирит. Содержание апатитов первого морфологического типа в среднем составляет 30 \% от общего объема минерала в породе. II морфотип образуют желтые матовые удлиненные кристаллы гексагонального дипирамидально- призматического габитуса. Размер зерен 0.10-0.50 мм, коэффициент удлинения 2-4. Облик минерала представлен комбинацией призмы (1010) и дипирамиды (1011). Поверхность граней трещиноватая. Часто встречаемыми включениями в апатите этого вида являются кварц, плагиоклаз, циркон. Содержание апатитов второго морфологического типа в среднем составляет 70 \% от общего объема минерала в породе.

Ранее проведенное М.В. Фишманом и его коллегами (Фишман и др., 1968) изучение морфологии апатита из гранитных массивов Приполярного Урала показало, что между степенью развития граней пинакоида минерала и его температурой образования имеет место тесная связь. Так, при понижении температуры среды минералообразования относительный размер граней пинакоида апатита увеличивается и, соответственно, подавляется величина граней дипирамид. На основании выявленной взаимосвязи, можно утверждать, что апатит I типа является более низкотемпературным минералом, чем апатит II типа. Отличительной особенностью апатита является его хрупкость. Вследствие чего, маркером влияния наложенных процессов является степень коррозии граней минерала. Изучение граней акцессорного апатита Бадьяюского массива позволяет сделать вывод, что минерал первого морфотипа, обладающий более сильной коррозией граней, был сильнее подвержен на- 
ложенным процессам, и, вероятно, является поздней генерацией апатита. Относительное время образования каждого типа минерала можно определить по расплавным включениям в апатите. Среди минеральных включений, отмеченных в апатите I типа, встречается пирит, который, согласно последовательности кристаллизации минералов для гранитоидов Приполярного Урала (Фишман и др., 1968) выделяется на поздней стадии гранитогенеза. В свою очередь, плагиоклаз, отмечаемый в виде включения только в апатите II типа, формируется на ранней стадии формирования гранитов. Это подтверждает сделанное ранее предположение, апатит первого морфологического типа является поздней генерации минерала.

Характерной особенностью апатита является влияние элементов- примесей на цвет минерала; $\mathrm{Mn}^{5+}$ придает минералу голубой цвет, $\mathrm{Sm}^{2+}$ отмечается у розовых апатитов, наличие $\mathrm{Pr}^{3+}$ проявляется в виде зеленых тонов. Присутствие $\mathrm{Fe}^{3+}$ предает кристаллам апатита желтый цвет, в случае сильной насыщенности железом зерна приобретают коричневый цвет. Среди апатитов Бадьяюского гранитного массива отмечаются минералы желтого цвета различной интенсивности. По насыщенности цвета апатита можно сделать вывод, что в составе изученных кристаллов содержится примесь железа в заметных количествах. Причем, основываясь на интенсивности окраски минералов, среднее содержание железа в апатите второго типа больше, чем в апатите первого типа. Это подтверждает анализ химических составов апатитов изученного массива, в результате которого выявлено различие в содержании оксида железа: $\mathrm{FeO}$ в апатите II типа (кристаллы желтого цвета) в среднем выше на 33.9 \%, чем в апатите I типа (зерна светло-желтого цвета) (Осовецкий, 2001).

Исследованные минералы относятся к фтористой разновидности: $\mathrm{F}_{\text {I тип }}=1.43-2.47 \%$ и в среднем $2.09 \%$; $\mathrm{F}_{\text {I тип }}=1.69-2.33 \%$ и в среднем $2.31 \%$. Так же для апатитов Бадьяюского массива определены индикаторные отношения $\mathrm{F} / \mathrm{Cl}$ : $\mathrm{F} / \mathrm{Cl}{ }_{\text {I тип }}=15.8$ - 16.9 и в среднем 16.2 ; $\mathrm{F} / \mathrm{Cl}_{\text {II тип }}=16.1-17.5$ и в среднем 16.5. Это отношение является показателем гегнезиса породы: для осадочных пород составляет 150-200, для метаморфических апатитов - 10-30, для изверженных пород - 15-19. Отношение $\mathrm{F} / \mathrm{Cl}$, рассчитанное для бадьяюских апатитов, указывает на магматическое происхождение минералов.

\section{Температура образования апатита Бадьяюского массива}

Исследования Е. Ватсона и Т. Харрисона (Harrison, Watson, 1984) показали, что апатит может использоваться в качестве геотермометра. В ходе многолетних изучений ученые установили взаимосвязь между уровнем насыщения фосфором в метаалюминиевой породе (A/CNK $<1)$, содержанием кремнезема и температурой:

$$
\begin{gathered}
\mathrm{InD}_{\mathrm{p}}=\left(8400+26400\left(\mathrm{SiO}_{2}-0.5\right)\right) / \mathrm{T}-3.1-12.4\left(\mathrm{SiO}_{2}-0.5\right), \mathrm{P}_{2} \mathrm{O}_{5}(\mathrm{HW})=42 / \mathrm{D}_{\mathrm{p} .} \\
\mathrm{T}^{\mathrm{C}}=\left(8400+26400\left(\mathrm{SiO}_{2}-0.5\right)\right) /\left(\operatorname{In}\left(42 / \mathrm{P}_{2} \mathrm{O}_{5}\right)+3.1+12.4\left(\mathrm{SiO}_{2}-0.5\right)\right)-273.15 .
\end{gathered}
$$

где $\mathrm{D}_{\mathrm{p}}$ - соотношение концентрации $\mathrm{P}$ в апатите и расплаве, $\mathrm{P}_{2} \mathrm{O}_{5}, \mathrm{SiO}_{2}$ - весовая доля оксида фосфоpa, кремнезема в расплаве, масс. вес, Т - температура, Кельвин.

Ф. Беа с коллегами (Веа и др.,1992) доработал эти формулы для пералюминиевых пород (А/ $\mathrm{CNK}>1)$.

$$
\begin{gathered}
\mathrm{P}_{2} \mathrm{O}_{5}(\mathrm{Bea})=\mathrm{P}_{2} \mathrm{O}_{5}(\mathrm{HW}) * \exp (6429(\mathrm{~A} / \mathrm{CNK}-1) /(\mathrm{T}-273.15)) ; \\
\text { где } \mathrm{A} / \mathrm{CNK}=\mathrm{Al}_{2} \mathrm{O}_{3} /\left(\mathrm{CaO}+\mathrm{Na}_{2} \mathrm{O}+\mathrm{K}_{2} \mathrm{O}\right) . \\
\mathrm{T}^{\mathrm{C}}=\left(8400+26400\left(\mathrm{SiO}_{2}-0.5\right)\right) /\left(\mathrm { In } \left(42 / \mathrm{P}_{2} \mathrm{O}_{5}{ }^{*}\right.\right. \\
\left.\exp (6429(\mathrm{~A} / \mathrm{CNK}-1) /(\mathrm{T}-273.15)))+3.1+12.4\left(\mathrm{SiO}_{2}-0.5\right)\right)-273.15 .
\end{gathered}
$$

На основе данных по химическому составу гранитов Бадьяюского массива, автором были получены температуры насыщения для апатита и апатитсодержащей породы (гранита). Согласно проведенным расчетам, бадьюский апатит кристаллизовался при температурах от $634^{\circ} \mathrm{C}$ до $863{ }^{\circ} \mathrm{C}$. Это позволяет говорить о гранитах Бадьяюского массива как о высокотемпературных образованиях. 


\section{Заключение}

Изучение акцессорного апатита из гранитов Бадьяюского массива показало, что минерал представлен двумя морфологическими типами: гексагонального призматического габитуса (I тип) и гексагонального дипирамидально- призматического габитуса (II тип). На основе степени развития граней пинакоида кристалла, степени коррозии граней минерала и расплавных включений установлено, что апатит I типа является поздней и более низкотемпературной генерацией минерала, чем апатит II типа.

На основе формул Е. Ватсона, Т. Харрисона и Ф. Беа определено, бадьяюский апатит образовался при температурах от $634^{\circ} \mathrm{C}$ до $863^{\circ} \mathrm{C}$. Согласно М. В. Фишману и его коллегам, апатит сальнеро- маньхамбовского комплекса, к которому относиться рассматриваемый массив, мог кристаллизоваться во время ранней стадии и начале поздней стадии магматического этапа гранитогенеза. Это позволяет утверждать, что формирование пород Бадьяюского массива проходило при высоких температурах. Это подтверждает более ранние данные выводы автора, согласно которым температурный диапазон образования гранитов Бадьяюского массива составляет: на основе термометрии насыщения Ватсона по циркону - 773 до $912^{\circ} \mathrm{C}$, эволюционного кристалломорфологического анализа Пюпена - от 750 до $900^{\circ} \mathrm{C}$ (Денисова, 2016, 2018, 2019).

Исследованияпроведеныв рамках НИРИГКомиНЦУрОРАНГР №АААА-А 17-117121270035-0 и при финансовой поддержке Программы фундаментальных исследований РАН № 18-5-5-19.

\section{Литература}

1. Денисова Ю.В. Термометрия циркона из гранитоидов Приполярного Урала // Вестник Института геологии Коми НЦ УрО РАН. Сыктывкар. № 12. 2016. С. 37-44.

2. Денисова Ю.В. Апатит Николайшорского гранитного массива (Приполярный Урал) // Вестник Института геологии Коми НЦ УрО РАН. Сыктывкар. № 9. 2018. С. 24-29.

3. Денисова Ю.В. Термометрия насыщения циркона, апатита, монацита (Кожимский массив, Приполярный Урал) // Известия Коми научного центра УрО РАН. № 3 (39). Сыктывкар. 2019. С. 25-30. doi 10.19110/1994-5655-2019-3-47-52.

4. Махлаев Л.В. Гранитоиды севера Центрально- Уральского поднятия (Полярный и Приполярный Урал). Екатеринбург. Изд-во: УрО РАН. 1996. 189 с.

5. Осовецкий Б.М. Типохимизм шлиховых минералов. Пермь. Изд- во: Пермск. ун- та. 2001. 244 с.

6. Фишман М.В., Юшкин Н.П., Голдин Б.А., Калинин Е.П. Минералогия, типоморфизм и генезис акцессорных минералов изверженных пород севера Урала и Тимана. М.- Л. Изд-во: Наука. 1968. 252 с.

7. Bea F., Fershtater G.B., Corretgé L.G. The geochemistry of phosphorus in granite rocks and the effects of aluminium // Lithos. 1992. V. 48, P. 43-56.

8. Harrison T.M. and Watson E.B. The behavior of apatite during crustal anatexis: Equilibrium and kinetic considerations // Geochim. Cosmochim. Acta. 1984. V. 48. P. 1467-1477. 